\title{
Teoriden Uygulamaya Bilimsel Sorgulama ve Bilimsel Sorgulamanın Doğası
}

DOI: $10.26466 /$ opus. 861829

\author{
Eda Erdaș Kartal* - Günkut Mesci** \\ * Dr., Kastamonu Üniversitesi \\ E-Posta: erdaseda@gmail.com \\ ORCID: $0000-0002-1568-827 \mathrm{X}$ \\ ** Dr., Giresun Üniversitesi \\ E-Posta: gunkutmesci@gmail.com \\ ORCID: $\underline{0000-0003-0319-5993}$
}

\begin{abstract}
$\ddot{O} z$
Günümüzde birçok ülkenin fen öğretim programının ana vizyonu bilim okuryazarı bireyler yetiştirmektir. Bilimsel sorgulama ve bilimin doğası bilim okuryazarlığının temel bileşenlerindendir. Bilimsel sorgulama çoğunlukla bilimin doğası ile karıştırılmakta ya da aynı kavrammış gibi ele alınmaktadır. Bilimsel sorgulama bilimsel bilginin üretildiği süreç, bilimin doğası ise bu süreç sonunda ortaya çıkan bilimsel bilginin özellikleridir. Bilimsel sorgulama beceri ve anlayış kazandırma olarak iki boyutta ele alınmaktadır. Bilimsel sorgulamanın beceri boyutu ile ele alınması tek başına bilimsel sorgulama hakkında anlayış kazanmayı garantilememektedir. Bilimsel sorgulama hakkında anlayış kazandırma, öğrencilere bilimsel sorgulama sürecinin özellikleri hakkında yani bilimsel sorgulamanın doğası hakkında anlayış kazandırmaktır. Bilimsel sorgulamanın doğası hakkında yapılan çalışmaların çoğu hem öğrencilerin hem de öğretmen ve öğretmen adaylarının bilimsel sorgulamanın doğası hakkında yetersiz görüşlere sahip oldukların ortaya koymaktadır. Bilimsel sorgulamanın doğasının konu içeriği olarak ele alınıp içerik tabanlı veya klasik etkinliklerle açık/yansıtıcı yaklaşımlarla öğretilmesi, öğretimde bilimsel sorgulamanın sımı içi etkinliklerde uygulanması kadar önemlidir. Bu bağlamda öğrencilerin, öğretmenlerin ve öğretmen adaylarının bilimsel sorgulamanın doğası görüşlerinin geliştirilmesi için araştırmalar yapılması önerilmektedir.
\end{abstract}

Anahtar Kelimeler: bilimsel sorgulama, bilimsel sorgulamanın doğası, bilimsel okur yazarlı 


\title{
Scientific Inquiry and Nature Of Scientific İnquiry From Theory To Practice
}

\begin{abstract}
The main objective of science education programs of many countries is to raise scientifically literate individuals. Scientific inquiry and nature of science are essential components of science literacy. Scientific inquiry is often confused with nature of science or handled as if it is the same concept. Scientific inquiry is the process by which scientific knowledge is produced, while nature of science is the characteristics of scientific knowledge that produces at the end of this process. Scientific inquiry is considered in two dimensions as gaining skill and understanding. Dealing with scientific inquiry with the skill dimension alone does not guarantee an understanding of scientific inquiry. To gain an understanding about scientific inquiry is to give students an understanding of the features of the scientific inquiry process. Most of the studies on the nature of scientific inquiry reveal that students, in-service teachers and pre-service teachers have insufficient views about the nature of scientific inquiry. Taking the nature of scientific inquiry as subject content and taught with explicit/reflective approaches with content-based or classical activities as important as applying scientific inquiry in classroom activities. In this context, it is recommended to conduct more studies to develop the nature of scientific inquiry understanding of students, in-service teachers and pre-service teachers.
\end{abstract}

Keywords: scientific inquiry, nature of scientific inquiry, science literacy 


\section{Giriş}

Araştıran, sorgulayan, üreten ve değişime ayak uydurabilen, üst düzey düşünme becerilerine sahip bilim okur yazarı bireylerin yetiştirilmesi; çeşitli ülkelerin öğretim programlarının öncelikli hedefi olduğu gibi (American Association for the Advancement of Science (AAAS), 1993; National Research Council (NRC), 2011; New Generation Science Standarts (NGSS), Lead State, 2013), ülkemizin fen öğretim programının en temel hedefi ve vizyonudur (Milli Eğitim Bakanlığı (MEB), 2018). Bilimsel okuryazarlık aslında bilimsel bilgileri bilmek, bilimsel bilginin doğasını ve bu bilgilerin nasıl üretildiğini anlamak, bilim teknoloji ve toplumun birbirini nasıl etkilediğinin farkında olmak, bilim ve teknoloji ile ilgili olumlu tutum ve değer yargılarına sahip olmak, bu bilgilerini ve farkındalığını gündelik hayatında kullanabilmektir (NRC, 1996). Tanımlardan anlaşılabileceği ve fen eğitimcilerinin vurguladı̆̆ı gibi bilimin doğası ve bilimsel sorgulama bilim okuryazarlığının temel bileşenlerinden ikisidir (Flick ve Lederman, 2006; Deniz ve Akerson, 2013; Lederman, Antink ve Bartos, 2014; Lederman ve Lederman, 2012; Lederman, Lederman ve Antink, 2013; NGSS, 2014).

Son olarak 2018 yılında yeniden güncellenen fen öğretim programımızda; bilim okuryazarı bireyler yetiştirmek doğrultusunda belirlenen özel amaçlar arasında "doğanın keşfedilmesi ve insan-çevre arasındaki ilişkinin anlaşılması sürecinde, bilimsel süreç becerileri ve bilimsel araştırma yaklaşımını benimseyip bu alanlarda karşılaşılan sorunlara çözüm üretmek" ve "bilim insanlarınca bilimsel bilginin nasıl oluşturulduğunu, oluşturulan bu bilginin geçtiği süreçleri ve yeni araştırmalarda nasıl kullanıldığını anlamaya yardımcı olmak" bulunmaktadır. Bu özel amaçlardan da anlaşılabileceği gibi öğretim programında hem bilimsel sorgulamanın kullanılmasına hem de bilimsel sorgulama süreçlerinin özellikleri olarak tanımlanan bilimsel sorgulamanın doğasının anlaşılmasına ilişkin özel vurgular yer almaktadır (MEB, 2018). Ancak uygulamalarda bilimsel sorgulamanın sınıf içi fen öğretimindeki yeri, tam olarak neyi kapsadığı, hangi uygulamaların bilimsel sorgulama olduğu veya olmadığı konusunda çeşitli tartışmalar ve yanılgılar bulunmaktadır (Bybee, 2000; Crawford, 2014; Duschl, Schweingruber ve Souse, 2007). Çoğu zaman, bilimsel süreç becerilerinin kullanıldığı her uygulamalı bilimsel etkinlikte, bilimsel sorgulama yapıldığı düşünülmektedir (Lederman vd., 2014). Bazı durumlarda ise, bir etkinliğin bilimsel sorgulama olabilmesi için, 
mutlaka öğrencilerin öğretmen rehberliğinden uzak bir şekilde, araştırma problemlerini kendilerinin belirlemesi gerektiği anlayışı mevcuttur (Crawford, 2014). Diğer taraftan yapılan çalışmaların azımsanmayacak bir kısmında, bilimsel sorgulamanın doğasını anlamak (knowledge about nature of scientific inquiry) için bilimsel sorgulama yapmış olmak (doing inquiry) yeterli bulunmaktadır. Bilimsel sorgulamanın doğasını anlamak bilimin doğasını anlamak ile karıştırılmakta ya da birbiri ile eş tutulmaktadır (Lederman vd., 2014). Özetle bilimsel sorgulamanın öğretimi düşüncesi fen eğitiminde uzun bir tarihi geçmişe sahip olmasına rağmen, bilimsel sorgulamanın öğretimi ile neyin kastedildiği konusunda günümüzde hala bir karmaşa bulunmaktadır (Bell, Smetena ve Bills, 2005; Bybee, 2000; Lederman vd., 2014). Bu karmaşadan kurtulmak için bilimsel sorgulamanın tam olarak ne olduğu ve neleri kapsadığının açık bir şekilde ifade edildiği, bilimsel sorgulamanın bilimin doğasından hangi yönleri ile farklılaştı̆̆ının ortaya konulduğu teorik çalışmalara ihtiyaç olduğu düşünülmektedir. Ülkemizde de benzer bir şekilde bilimin doğası uzun yıllardır çalışılıyor olmasına rağmen, bilimsel sorgulamanın sınıf içi fen öğretiminde neye karşılık geldiği, öğrencilerin veya öğretmenlerin bilimsel sorgulama hakkındaki anlayışlarının tespit edilmesi, bir taraftan bilimsel sorgulama yaptırılırken diğer taraftan bilimsel sorgulamanın doğası hakkında anlayışların nasıl geliştirilebileceği konusunda araştırmacıların ve öğretmenlerin faydalanabileceği oldukça sınırlı doküman bulunmaktadır (Mesci ve Erdaş-Kartal, 2021). Bu çalışma, ulusal alan yazındaki bu boşluğu doldurmaya yönelik hazırlanmış kuramsal bir araştırmadır.

\section{Bilimsel Sorgulama ve Bilimin Doğası Arasındaki İlişki}

Bilimsel sorgulamanın ve bilimin doğasının belirli nitelikleri ile bunların mevcut fen öğretimine ve fen programına entegrasyonu konusunda öğretmenler ve fen eğitimcileri hala çeşitli belirsizlikler yaşamaktadır (Flick ve Lederman, 2006; Park, 2008). Bilimsel sorgulama ve bilimin doğası kavramları çoğu zaman birbirinin yerine kullanılmaktadır (Lederman vd, 2014). Bilimin doğası ve bilimsel sorgulama her ne kadar birbiri ile yakın ilişkide olsalar da birbirinden farklı yapılardaki kavramlardır (Flick ve Lederman, 2006; Lederman, 2019).

Bilimin doğası, bir insan performansı olan bilimsel sorgulama sonucunda üretilen bilimsel bilgilerin kullanımını ve ontolojik durumunu sınırlayan ve 
sinırlamayan belirli özellikleri ifade etmektedir (Flick ve Lederman, 2006). Daha anlaşılır bir ifade ile bilimin doğası, bilimsel sorgulama sürecinde üretilen bilimsel bilginin üretiminin ve gelişiminin doğasında var olan değerler ve varsayımlardır (Lederman, 1992). Bilimsel sorgulama, bilim insanlarının işlerini nasıl yaptıkları ve ortaya çıkan bilimsel bilginin nasıl üretilip kabul edildiğine ilişkin somut süreçleri ifade ederken; bilimin doğası, bilimsel bilginin nasıl geliştirildiğinden yola çıkarak türetilen bilimsel bilginin özelliklerine, bilimi din ve tarih gibi disiplinlerden ayıran özelliklerine atıf yapmaktadır (Nehring, 2019; NGSS, 2013; Lederman, 2006; Lederman vd., 2014).

Peki bilimsel sorgulama nedir ve ne değildir? Bilimsel sorgulama sınıf içi fen öğretiminde tam olarak neye karşılık gelmektedir? Şimdiye kadar yaptırdığımız uygulamalı fen etkinliklerinin bilimsel sorgulama olduğundan ne kadar eminiz? Bu sorulara cevap bulabilmek için öncelikle bilimsel sorgulamanın tanımını net bir şekilde yapmak ve sınıf içinde yapılan bilimsel sorgulama faaliyetleri ile ilgili çeşitli mitlere değinmek gerekmektedir.

Anderson (2002) sorgulamanın üç farklı anlamda kullanıldığının altını çizmektedir. Buna göre alan yazında bilimsel sorgulama kavramı; (1) bilimsel araştırma (bilim insanlarının doğal dünyayı inceledikleri çeşitli yollar), (2) sorgulayıc öğrenme (öğrencilerin fen kavramları hakkındaki bilgilerini bir araya getirdikleri ve bilimin doğasını öğrendikleri bir süreç), ve (3) sorgulama öğretimi (geniş anlamda, öğretmenlerin öğrencileri sorgulamaya dahil ettiği pedagoji olarak tanımlanır) kavramlarına karşılık gelen anlamlarda kullanılmaktadır. Bilimsel sorgulama, basit tanımıyla, bilim insanlarının dünyayı anlamak ve açıklamak için yürüttükleri sistematik araştırma aktivitelerinin bütünüdür (Lederman ve Lederman, 2012; NRC, 2000). Bilimsel sorgulama süreci; araştıılacak konu ile ilgili sorular sormayı, araştırmayı planlamayı ve uygulamayı, matematiksel düşünmeyi, verileri analiz etmeyi ve yorumlamayı, bulguların paylaşılması ve tartışılması kısmında olguların delilleriyle birlikte açıklanmasını ve bu doğrultuda iletişim becerilerinin etkili bir şekilde kullanılmasını içermektedir (NRC, 2012; Pedaste vd., 2015). Bilimsel sorgulama deneyimleri bireylere bilimsel bilgi ve iddiaların doğası ve sınırları hakkında düşünebilecekleri temel deneyimler sağlamaktadır (Lederman, 2006). Bilimsel sorgulama geleneksel bilim süreçlerini içermekte, fakat aynı zamanda bilimsel bilgi geliştirmek için bu süreçlerin bilimsel bilgi, bilimsel akıl yürütme ve eleştirel düşünme ile birleştirilmesini ifade etmektedir (Lederman, Antink ve Bartos, 2014). 
Bilimsel sorgulama daha net bir ifadeyle, öğrencilerin araştırma sorularını veri analizi yoluyla yanıtladıkları aktif bir öğrenme sürecidir (Bell, Smetena ve Bills, 2005; Crawford, 2014). Öğrencilerin kendi sorularını bağımsız olarak yapılandırdıkları ve topladıkları verileri analiz ederek bu soruları yanıtladıkları etkinlikler bilimsel sorgulama olarak kabul edilmektedir. Bunun yanı sıra, öğretmenlerin araştırma sorusunu ve yöntemi belirlediği, öğrencilerin ise verileri analiz edip kendi sonuçlarını çıkarttıkları araştırmalar da sorgulamaya dahil edilmektedir. Bir etkinliğin bilimsel sorgulama olarak kabul edilebilmesi için önemli olan bir araştırma sorusuyla başlaması ve bu sorunun yanitlanması amaciyla toplanan verilerin analizinin yapılmasıdır (Bell, Smetena ve Bills, 2005). Fen öğretiminde sınıflarda yapılan etkinliklerin bir kısmı önemli olmakla birlikte araştırma sorusu belirlemeyi ve veri analizini içermemektedir. Öğretmenlerin sorgulamaya dayalı öğretimin uygulamalı (handson) veya kit-tabanlı (kit-based) öğretim materyallerinin kullanımı ile basit bir şekilde sağlanabileceğine yönelik yanlış bir algıları bulunmaktadır. Ancak uygulamalı etkinlikler fen eğitiminde önemli olmakla birlikte bir araştırma sorusuna yanıt aranmadığı ve bu doğrultuda veri analizi yapılmadığı durumlarda sorgulama olarak kabul edilmemektedir (Crawford, 2014). Bir atom modeli, hücre modeli oluşturmak veya basit bir teleskop yaptırmak fen öğretimi için ideal ve önemli etkinlikler olabilirler; ancak bu etkinlikler sınıflardaki geleneksel yaptırılış şekilleriyle bir araştırma sorusu içermemektedirler. Dolayısıyla bu tür etkinlikler bilimsel sorgulama olarak kabul edilemezler. Yine belli bir beceriyi sergilemeyi ve geliştirmeyi hedefleyen mikroskopta bitki ve hayvan hücresinin görüntüsünü elde etmek gibi etkinlikler de fen öğretimi için gerekli ancak araştırma sorusu içermeyen etkinliklerdir. Dolayisiyla bu tarz etkinlikler de bilimsel sorgulama olarak kabul edilemezler (Bell, Smetena ve Bills, 2005). Sorgulama etkinlikleri, bir araştırma sorusuna yanıt aramanın yanı sıra, öğrencilerin veri analizi yapmasını gerektirmektedir. Burada bahsedilen bir konu hakkında öğrencileri kütüphanelerden, kitaplardan veya çeşitli internet kaynaklarından bilgi toplamaya yönlendirmek değildir. Çünkü öğretmenin yaptırdığı böyle bir etkinlikte öğrenciler çoğunlukla sadece bilgi toplarlar ve bu bilgileri analiz etmezler (Bell, Smetena ve Bills, 2005). Burada kritik nokta, bu aktivitenin bilimsel sorgulama kabul edilebilmesi için öğrencilerin topladıkları verileri araştırma problemlerine yanıt oluşturmak amacıyla analiz etmelerinin gerektiğidir. Bu süreçte öğrencilerin veri toplaması şart değildir. Öğretmen tarafından kendilerine sunulan hazır 
verileri, araştırma problemlerine yanıt oluşturacak şekilde analiz etmeleri bilimsel sorgulamanın yapılmış olması için yeterlidir (Bell, Smetena ve Bills, 2005). Buna karşılık alan yazında bilimsel sorgulamanın sınıf içi uygulamaları ile ilgili çeşitli mitler ve kavram yanılgıları bulunmaktadır. Bunlar beş maddede özetlenebilir:

1. Tüm fen konuları bilimsel sorgulamayla öğretilmelidir.

2. Doğru bilimsel sorgulama öğrencilerin kendi sorularını oluşturmalarını ve süreci kendilerinin yönetmelerini gerektirir.

3. Bilimsel sorgulama uygulamalı ve kit tabanlı öğretim materyalleri kullanılarak kolay bir şekilde gerçekleştirilebilir.

4. Öğrencilerin uygulamalı etkinliklere katılımı sorgulamaya dayalı öğretimi ve bilimsel sorgulamayı öğrenmeyi garantiler.

5. Bilimsel sorgulama konu alanına önem vermeden kullanılabilir ve öğretilebilir (Crawford, 2014).

\section{Bilimsel Sorgulamanın Düzeyleri}

Bilimsel sorgulama ile ilgili mevcut mitlerde de yer verildiği gibi doğru ve gerçek bilimsel sorgulamanın sadece öğrencilerin sorularını kendilerinin ürettikleri ve süreci kendilerinin yönettikleri durumlarda yapıldığına yönelik yanlış bir algı bulunmaktadır (Crawford, 2014). Evet bu bir sorgulamadır; ancak sorgulama düzeylerinden sadece bir tanesidir. Tüm sorgulamaların aynı düzeyde yapılmadığını veya yapılmak zorunda olmadığını kavramak önemlidir (Bell, Smetena ve Bills, 2005). Sorgulamanın farklı düzeylerde yapılabileceği ilk kez Schwab (1962) tarafından ifade edilmiş, akabinde Herron (1971) sorgulama sürecinde nelere yer verildiğine bağlı olarak 3 farklı sorgulama düzeyi tanımlamıştır. Rezba, Auldridge ve Rhea (1999), Herron'un çalışmasını temel alarak dört farklı sorgulama düzeyi tanımlamıştır. Bu dört sorgulama düzeyi ile ilgili ayrıntılı bir değerlendirmeye Sorgulama ve Ulusal Fen Eğitimi Standartları'nda (Inquiry and the National Science Education Standards) yer verilmiştir (NRC 2000, akt: Bell, Smetena ve Bills, 2005).

Bilimsel sorgulamanın, öğrencilere sağlanan bilgi ve yaptırılan sorgulamanın karmaşıklığına göre doğrulama (confirmation), yapılandırılmış sorgulama (structured inquiry), rehberli sorgulama (guided inquiry) ve açk sorgulama (open inquiry) olmak üzere dört düzeyi bulunmaktadır (Rezba, Auld- 
ridge ve Rhea, 1999). Doğrulama düzeyindeki sorgulamada öğrenciler araştırma sorusu, bu soruyu çözmede kullanacakları yöntem ve sorunun olası çözümleri hakkında sorgulama öncesinde bilgi sahibidir. Yapılandırılmış sorgulamada öğrencilere araştırma soru ve yöntemi hakkında bilgi verilmektedir. Rehberli sorgulamada sadece araştırma sorusu verilmekte iken açık sorgulamada araştırma sorusu da öğrenciler tarafından belirlenmektedir (Tablo $1)$.

Tablo 1. Sorgulama Düzeyleri ve Özellikleri (Rezba, Auldridge ve Rhea, 1999; Bell, Smetena ve Bills, 2005)

\begin{tabular}{|c|c|c|c|c|}
\hline $\begin{array}{l}\text { Sorgu- } \\
\text { lama } \\
\text { Düzeyi }\end{array}$ & Tanım & $\begin{array}{l}\text { Araştırma } \\
\text { sorusu }\end{array}$ & Yöntem & Sonuçlar \\
\hline 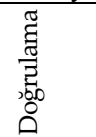 & $\begin{array}{l}\text { Sonuçları önceden bilinen bilimsel bir etkinli- } \\
\text { ğin doğrulanması amacıyla yapılan bilimsel } \\
\text { sorgulamalardır. }\end{array}$ & Öğretmen & Öğretmen & $\begin{array}{l}\text { Öğret- } \\
\text { men }\end{array}$ \\
\hline 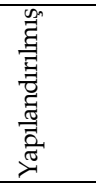 & $\begin{array}{l}\text { Öğretmen tarafından verilen bir araştırma so- } \\
\text { rusunun öğretmen tarafından tanılanan pro- } \\
\text { sedürlerin izlenmesi ile gerçekleştirilen sorgu- } \\
\text { lamalardır. Öğrenciler sonuçlar hakkında önce- } \\
\text { den bilgiye sahip değildir. }\end{array}$ & Öğretmen & Öğretmen & Öğrenci \\
\hline 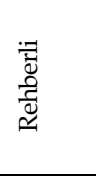 & $\begin{array}{l}\text { Öğretmen tarafından verilen araştırma sorusu } \\
\text { ile ilgili varsa hipotezlerin öğrenciler tarafında } \\
\text { üretildiği, araştırma sorusunun öğrencilerin } \\
\text { kendi tasarladıkları prosedürlerle izlenerek ya- } \\
\text { nıtlanmaya çalışılığı sorgulamalardır. }\end{array}$ & Öğretmen & Öğrenci & Öğrenci \\
\hline 慈 & $\begin{array}{l}\text { Tanımlanmış bir konuyla alakalı yapılacak } \\
\text { araştırmanı tamamen öğrenci tarafından ta- } \\
\text { sarlandığı, yani araştırma sorusunun ve izlene- } \\
\text { cek prosedürlerin öğrenci tarafından belirlen- } \\
\text { diği, olasıs sonuçların önceden bilinmediği sor- } \\
\text { gulamalardır. }\end{array}$ & Öğrenci & Öğrenci & Öğrenci \\
\hline
\end{tabular}

Doğrulama düzeyindeki ve yapılandırılmış düzeydeki bilimsel sorgulamalara hem sorunun hem de sorunun çözümünde takip edilecek prosedürün adım adım öğrenciye sunulduğu geleneksel laboratuvar etkinlikleri örnek verilebilir (Bell, Smetena ve Bills, 2005). Bu tarz sorgulamalar basit düzeyde sorgulama sağlamakla birlikte, bir araştırma sorusu ve bu araştırma sorusunu çözmeye yönelik elde edilen verilerin analizini gerektirdiği için sorgulama olarak kabul edilmektedirler. İkisinin arasındaki fark doğrulama düzeyinde yapılan sorgulamaların genellikle konu içeriği öğrenildikten sonra 
yaptırılması yani öğrencilerin araştırma sorusunun olası cevapları konusunda bilgi sahibi olmalarıdır (Bell, Smetena ve Bills, 2005; Buck, Bretz ve Towns, 2008; Bunterm vd., 2014). Ders kitaplarında sunulan mevcut fen laboratuvar uygulamaları çoğunlukla bu iki düzeyde sorgulamayı içermektedir. Düşük düzeydeki sorgulamaların kullanılmasının, daha karmaşık ve yüksek düzeydeki sorgulamaları müfredattan dışlamadığı sürece, bir zararı bulunmamaktadır. Hatta alt seviye sorgulamalardan başlanıp, dönem boyunca yaptırılan sorgulama düzeyinin aşamalı bir şekilde arttırılması, öğrencilerin sorgulama hakkında kendilerine bir temel oluşturmalarını sağlayabilir (Bell, Smetena ve Bills, 2005).

Öğretmen, doğrulama düzeyindeki sorgulamayı konu öğrenilmeden öncesine çekerek, yapılandırılmış düzeyde bir sorgulamaya; yapılandırılmış düzeydeki sorgulamayı ise, bu sorgulamada adım adım izlenmesini istediğ $i$ prosedürleri kaldırarak, rehberli sorgulama düzeyine taşıyabilmektedir (Banchi ve Bell, 2008; Bunterm vd., 2014). Açık sorgulama düzeyindeki etkinliklere bilim şenliklerinde sunulmak üzere hazırlanan bilim projeleri örnek verilebilir. Burada araştırma sorusu da öğrenciler tarafından belirlenmekte ve araştırma süreci tamamen öğrencilerin kontrolüne bırakılmaktadır (Bell, Smetena ve Bills, 2005; Martin-Hansen, 2002; Rezba, Auldridge ve Rhea, 1999; Sadeh ve Zion, 2009). Fen öğretiminde amaç öğrencileri açık sorgulama düzeyine çıkarmak olsa da kademeli ilerleyişin öğrencileri bu düzeydeki bir sorgulamaya hazırlama rolü göz ardı edilmemeli, sınıf içindeki sorgulamaya dayalı tüm fen etkinliklerinin açık sorgulama düzeyinde yapılması beklenmemelidir (Bell, Smetena ve Bills, 2005).

\section{Sorgulama Olarak Fen Öğretimi}

Bilimsel sorgulama, öğrencilere bilimin ne olduğunu öğretmek için kullantlan bir öğretim yaklaşımı olarak da görülmektedir (Abell, Smith ve Volkmann, 2006; Flick ve Lederman, 2006; Lotter, Harwood ve Bonner, 2006). Burada aslında bahsedilen bilimsel sorgulama değil sorgulama olarak fen öğretimidir. Sorgulama olarak fen öğretimi; öğrencilerin bilimsel sorgulamayı öğrenmeleri konusunda destekleyen, bilimsel kavramlar hakkındaki bilgilerini ve sorgulama süreçlerinin doğası hakkındaki bilgilerini geliştirmeyi amaçlayan pedagojik bir yaklaşım olarak tanımlanabilir (Crawford, 2014). 
Bilimsel sorgulamaya dayalı öğretim yaklaşımı öğrencilerin yapılandırmacı yaklaşıma uygun olarak bilgi ve becerilerini aktif bir şekilde oluşturmalarına imkân sağlamaktadır (Minner, Levy ve Century, 2009). Bu yaklaşım öğrencilerin etraflarında olup bitenleri anlamlandırma sürecinde mantıklı ve alternatif açiklamalar üretebilmelerini, bu süreçte sorgulayıcı ve eleştirel bir bakış açısı kazanmalarını sağlamaktadır (Anderson, 2002). Sorgulamaya dayalı öğretimin temelinde soru sorma, problem çözme ve eleştirel düşünme yer almaktadır. Bir araştırma sorusu ile başlamayı ve bu araştırma sorusuna yanıt aramak üzere toplanan veya öğrencilere hazır verilen verinin analiz edilmesini gerektirmektedir (Bell, Smetena ve Bills, 2005). Öğrenci merkezli bir yaklaşım olan sorgulamaya dayalı öğretim, öğrencilerin çağımızdaki hızlı değişim ve gelişime uyum sağlamalarını kolaylaştıracak becerileri kazanmalarını sağlamaktadır (Branch ve Solowan, 2003). Özellikle öğrenciler için çoğunlukla soyut kalan kavramların yoğun olduğu fen derslerinde, soyut kavramların somutlaştırılması ve kalıcı öğrenmenin sağlanması için bilimsel sorgulama yaklaşımının bu dersin ayrılmaz bir parçası olması önemlidir (Koyunlu-Ünlü, 2020; Bell, Urhahne, Schanze ve Ploetzner, 2010). Araştırmalar sorgulamaya dayalı fen öğretiminin geleneksel yaklaşımlara göre daha etkili bir yaklaşım olduğunu (Hodson, 2014; Oğuz-Ünver ve Yürümezoğlu, 2014; Wilson, Taylor, Kowalski ve Carlson, 2010), öğrencileri öğrenme sürecine daha fazla dahil ettiğini ve öğrencilerin öğrenme deneyimleri hakkında olumlu tutum kazanmalarını sağladığını ortaya koymaktadır (Anderson, 2002).

Fen öğretiminde sınıf içi sorgulamaların derecesinin, bilim insanları tarafından profesyonel bir şekilde yapılan sorgulamaların derecesinden farklı olduğu bilinen bir durumdur. Ancak zaten öğrenciler bilim insanlarının konu alanı ile ilgili sahip oldukları kadar derin bir bilgiye ve teknik uzmanlığa ulaşmak zorunda değildir (Crawford, 2014). Bu nedenle bilim insanlarının yaptıkları otantik sorgulamalarla, sınıf içi sorgulamaların hedefleri birbirinden farklılaşmaktadır. Araştırmacıların sorgulama olarak fen öğretiminden kastettikleri öğrencilerin bilimsel bir keşifle çözülen bir problemi kavramsallaştırmalarına izin vermek ve ardından cevapları kendilerine söylenmeden önce problemin olası cevaplarıyla boğuşmaya zorlamaktır (Bybee, 2006). Sorgulama olarak fen öğretiminin amacı, öğrencileri nasıl düşüneceklerini öğrenmeleri konusunda desteklerken bilimsel düşünme modelini kullanmaktır (AAAS, 1989). Öğrenciler bilim insanlarının bilimsel açılamalar üretirken 
yaptıkları gibi, modellerin nasıl yapılandırıldığını öğrenebilirler. Önemli olan öğrencilerin düzeyine uygun bir sorgulama etkinliği planlamaktır (Crawford, 2014).

Sorgulama olarak fen öğretiminin; proje temelli (poject-based), problem temelli (problem-based), otantik fen uygulamaları (authentic science), vatandaş bilimi (citizen science), model temelli sorgulama (model-based inquiry) gibi çeşitleri bulunmaktadır (Crawford, 2014). Hangi çeşidi kullanılırsa kullanılsın sorgulama olarak fen öğretiminin hem sorgulama yapmayı (doing inquiry, practices) hem de bir içerik olarak bilimsel sorgulamanın doğasını (nature of scientific inquiry) öğrenmeyi içerdiğini unutmamak oldukça kritiktir (Crawford, 2014). Çünkü sorgulama olarak fen öğretiminde; çoğu zaman öğrencilerin bilimsel sorgulamanın doğası hakkındaki bilgilerinin gelişip gelişmediği ayrı olarak değerlendirilmemekte ve öğrenciler sorgulama yaptıklarında bilimsel sorgulamanın doğasını öğrendikleri varsayılmaktadır (Lederman vd., 2014). Halbuki bilimsel sorgulama becerileri ile, bilimsel sorgulamanın özellikleri hakkında bir anlayışa sahip olma arasında fark vardır (NRC, 2000). Bilimsel sorgulama yaptırmak ve bilimsel süreç becerilerine sahip olmak elbette önemlidir ancak, öğrenciler bilim insanlarının çalışmalarını nasıl ve neden sürdürdüklerini bilmeden de bilimsel sorgulama yapabilirler (Lederman vd., 2019). Bir içerik olarak bilimsel sorgulamanın doğasını (nature of scientific inquiry) öğrenme boyutu göz ardı edildiğinde, sorgulama olarak fen öğretiminin amacına tam olarak ulaştı̆̆ı söylenemez.

\section{Bilimsel Sorgulamanın Doğası}

Yukarıdaki bölümde de bahsedildiği üzere sorgulama olarak fen öğretiminin iki temel çıkıısı bulunmaktadır. Bunlar bilimsel süreçleri yapabilme ve bu süreçler hakkında bilgi (bilimsel sorgulamanın doğası) sahibi olmadır. Uluslararası öğretim dokümanlarında da bilimsel sorgulamanın beceri ve anlayış olarak ayrı ayrı vurgulanması gerektiği ifade edilmektedir (NGSS, 2013).

Öğrencilerin bilimsel sorgulamanın doğasını anlamadan (knowledge about nature of scientific inquiry), bilimsel sorgulama prosedürlerini bilmeleri (knowledge about scientific inquiry) ve basit sorgulama deneyimlerine katılmaları (do scientific inquiry) onların bilimin epistemolojisini anlamalarının sağlanması ve sorgulama olarak fen öğretimi ile hedeflenen kazanımlara tam olarak ulaşılması açısından yeterli değildir (Lederman, 2006; Metz, 2004; 
Wong ve Hodson, 2010). Sahip olduğumuz bilgilerin kaynağını ve bu bilgilere neden inandığımızın açıklanması, sadece bilimsel bilginin oluşturulması sürecinin değil, aynı zamanda bu sürecin özelliklerinin de öğretilmesini, yani bilimsel sorgulamanın özellikleri/bileşenleri hakkında yeterli düzeyde anlayış kazandırılmasını gerektirmektedir (Schwartz, 2004; Osborne, 2014). Bireylerin ne yaptıkları hakkında bir anlayışa sahip olmaları; onların araştırma/uygulama yapma yeteneklerini geliştirebilir ve bu bilimsel bilgi ile birleştirildiğinde, bireylerin bilimsel temelli kişisel ve toplumsal konularda daha bilinçli kararlar vermelerini sağlayabilir (Lederman vd., 2019).

Bilimsel sorgulamanın doğası; bilimsel sorgulama sürecinin özelliklerini ifade etmektedir (Deniz ve Akerson, 2013; Lederman vd., 2014; Schwartz, 2004). Bu özelliklerin ne olduğu ile ilgili araştırmacıların ortak bir görüş benimsedikleri söylenebilir (Lederman vd., 2014; Osborne vd., 2003; Schwartz, Lederman ve Lederman, 2008). Buna göre bilimsel sorgulamanın bileşenleri 8 maddede özetlenebilir (Lederman vd., 2014; Lederman vd., 2019):

Tüm bilimsel araştırmalar bir soru ile başlar ancak her zaman bir hipotez test etmesi gerekmez: Bilimde gözlemler önemlidir ancak bilimin gözlemden ibaret olmadığını bilmek önemlidir. Yani tek başına bir şeyleri gözlemlemek bilim değildir. Bu gözlemlerin bilim olması için, gözlemlere rehberlik edecek bir araştırma sorusunun olması gerekmektedir. Bilimsel araştırmalar öğrencilerin merak ettikleri bir konuda bir soru ile başlayıp ulaştıkları bulguları var olan bilgilerle kıyaslamalarını gerektirmektedir ancak bilimsel araştırmaların mutlak suretle bir hipotezi test etmesi gerekmemektedir.

Tüm bilimsel araştırmalarda kullanılan tek ve adım adım takip edilen bir bilimsel yöntem yoktur: Bilimsel araştırmalar bilimsel yöntem gibi algilansa da bilimsel araştırma, deney yapmanın dışında, gözlem yapmak gibi değişik yollarla da gerçekleştirilebilir. Öğrencilerin bu yolların neler olduğunu bilmeleri tek başına yeterli değildir. Bunun yanı sıra bilimsel araştırmalarda kullanılan tek ve adım adım takip edilen bir bilimsel yöntem olmadığını kavramak da önemlidir. Bunu sağlamak amacıyla öğrencilere farklı yöntemler tasarlamaları ve yürütmeleri konusunda fırsatlar verilmelidir. 
Bilimsel sorgulama sürecine araştırma sorularn rehberlik eder: Bilimsel araştırmalarda yöntem olarak farklı prosedürler tasarlanabilse de bunların belirlenen soruyu yanıtlamaya uygun olmaları önemlidir. Yani öğrencilerin araştırma sorularını yanıtlamaya uygun, araştırma sorularına veri, ulaşmayı bekledikleri sonuçlara delil üretebilecek bir eylem planı hazırlamaları gerekmektedir. Bu yönüyle öğrencilerin tasarlayacakları prosedürlere araştırma sorularının yön vermesi gerektiği hakkında bir anlayışa sahip olmaları önemlidir.

Ayn işlemleri yapan tüm bilim insanları aynı sonuçlara ulaşamayabilirler: Bilim bir insan performansıdır. Bireysel farklılıklarımız, geçmiş araştırma deneyimlerimiz, ilgi alanlarımız, yetişmiş olduğumuz sosyoekonomik ve kültürel çevre farklı olabileceğinden dolayı, bir bilimsel araştırma sırasında elde edilen verilerin yorumlanmasında yorum farklılıklarının oluşması kaçınılmaz bir durumdur. Bu nedenle araştırmacılar aynı araştırma sorusuna aynı prosedürleri kullanarak yanıt arasalar bile farklı sonuçlara ulaşabilmektedirler.

Bilimsel sorgulama prosedürleri sonuçlar üzerinde etkili olabilir: Bir bilimsel araştırmada verilerin nasıl toplandığı, değişkenlerin nasıl ölçüldüğü ve analiz edildiği elde edilen sonuçları etkilemektedir. Örneğin teknolojik gelişmelerin veri toplama araçlarını ve yöntemlerini farklılaştırması, araştırmacıların elde ettikleri bulguları tarih boyunca değiştirmiştir. Bilimsel sorgulama olarak fen öğretiminde hedeflenen öğrencilerin yalnızca verileri analiz etme ve yorumlama konusunda beceri kazanmaları değil, aynı zamanda farklı yöntemlerle üretilen farklı veri setlerinden elde edilen sonuçları karşılaştırabilmeleridir. Bu doğrultuda öğrencilerin kullanılan farklı araştırma prosedürlerinin farklı sonuçlar üretebileceği hakkında bilgi sahibi olmaları da önemlidir.

Araştırma bulgularn ve toplanan veriler arasında tutarlılk olmalıdır: Bir bilim insanının iddiasının gücü, onu destekleyen delillerin üstünlüğü ile değerlendirilmektedir. Dolayısıyla öğrencilerin bilimsel araştırma sonucunda ürettikleri argümanların topladıkları verilerle tutarlı olması ve topladıkları verilerle desteklenmesi gerektiğini bilmeleri gerekmektedir.

Bilimsel veri ve bilimsel delil aynı şey değildir: Veriler bir bilimsel araştırma sırasında, araştırmacı tarafından elde edilen gözlemlerdir. Deliller ise topla- 
nan bu verilerin analizi ve yorumlanması ile elde edilen, araştırmacının iddialarını desteklemek amacıyla kullandığı ürünlerdir. Öğrencilerin veri ile delil arasındaki ayrımı anlaması, ortaya atılan iddialar ile ilgili hata kaynaklarını belirleyebilmeleri açısından önemlidir.

Bilimsel açıklamalar önceden bilinenler ve toplanan veriler ışığında geliştirilir: Bir bilimsel araştırma sonucunda üretilen argümanlar; araştırmacının araştırma sürecinde elde ettiği verileri, o konuda bilgi sahibi olduğu ve doğruluğu önceki araştırmaların bulgularıyla kabul görmüş açıklamalarla birleştirmesiyle ortaya koyulmaktadır. Örneğin dinazor kemikleri bulan bir paleontolog bu kemikleri iskeletin yapısı hakkında daha önceden bildiği bilgilerden yola çıkarak birleştirme girişiminde bulunmaktadır. Öğrencilerin bilimsel sorgulamanın doğasının bu bileşeni hakkında bilgi sahibi olmaları, kendi bulgularının önceki araştırmaların doğruluğu konusunda uzlaşılmış bulguları ile tutarlı olması gerektiği konusunda bir farkındalığa sahip olmaları açısindan önemlidir.

Araştırmacılar ve uluslararası reform dökümanları öğrencilerin bilimsel sorgulama yapma becerilerinin geliştirilmesinin öneminin yanı sıra, onların bilimsel sorgulama sürecinin yukarıda verilen özellikleri hakkında anlayış sahibi olmaları gerektiğini vurgulamaktadır (NRC, 2000; Lederman vd., 2019).

\section{Bilimsel Sorgulamanın Doğasının Öğretimi}

Bilimsel sorgulamanın doğası hakkında eğitim genellikle ilköğretimde başlamakla birlikte araştırmalar; erken çocukluk döneminde, yani okul öncesi dönemden itibaren ilk öğretimin ilk yıllarında da öğrencilerin bilimsel sorgulamanın bazı özelliklerini anlayabilme kapasitesine sahip olduklarını, dolayısıyla bu eğitimin mümkün olan en erken yaşta başlaması gerektiğini ortaya koymaktadır (Lederman, 2012; Lederman vd, 2019; NSGG, 2013; Tytler ve Peterson, 2003).

Yukarıdaki bölümlerde de ifade edildiği gibi öğrenciler bilim insanlarının çalışmalarını nasıl ve neden sürdürdüklerini bilmeden de bilimsel sorgulama yapabilmektedir (Lederman vd., 2019). Bu nedenle araştırmalar; bilimsel sorgulama yaptırma ile öğrencilerin bilimsel sorgulamanın doğası hakkındaki anlayışlarını dolaylı (implicit) bir şekilde geliştirmenin etkililiğini ciddi anlamda sorgulamaktadır (Lederman, Bartels, Liu ve Jimenez, 2013; Lederman 
ve Lederman, 2004; Schwartz vd., 2002; Schwartz, Lederman ve Crawford, 2004). Bilimin doğası ve bilimsel sorgulamanın doğasının epistemolojik ve pedagojik olarak birbiriyle ilişkili kavramlar olduğu düşünüldüğünde, uzun yıllardır bilimin doğası öğretiminde kullanılan yaklaşımlarla elde edilen sonuçlara bakarak bilimsel sorgulamanın doğası öğretiminde kullanılacak yaklaşımlarla ilgili çıarımda bulunmak mümkündür. Bu bağlamda, bilimsel sorgulamanın doğasının öğretimi sürecinde bilimsel sorgulamanın bileşenlerini açı/yansıtıcı (explicit/reflective) bir şekilde vurgulamak önemlidir (Leblebicioğlu vd, 2020; Lederman, 2019; Mesci, Çavuş-Güngören ve YesildagHasancebi, 2020). Öğrenci merkezli bir yaklaşım olarak değerlendirilen açı/yansıtıcı öğretim yaklaşımı (Khishfe ve Abd-El-Khalick, 2002), öğrencileri bilimsel bir araştırma sırasında ne yaptıkları, bu süreçte yapılanların bilim insanlarının çalışmalarını ve üretilen bilimsel bilgiyi nasıl etkilediği hakkında bağlantı kurabilmeleri, öğrencilerin bu süreçte elde ettikleri bilgileri önceki öğrenme deneyimleri ile ilişkilendirebilmeleri ve öğrencilerin öğrenmelerine açık geri bildirimler ile değerlendirme sürecidir. Bu yaklaşımla öğrencilerin bilimsel sorgulama yaparken aynı zamanda bilimsel sorgulamanın doğası hakkında anlayışlarını da geliştirebilmektedir (Khishfe ve Abd-ElKhalick, 2002).

\section{Bilimsel Sorgulamanın Doğası İle İlgili Görüşleri Belirlemeye Yönelik Geliştirilen Araçlar}

Yukardaki bölümlerde bahsedildiği gibi, bilimin doğası ve bilimsel sorgulamanın doğası çoğu zaman benzer kavramlar gibi algılanmış ve birbirinin yerine kullanılmıştır. Bu iki kavramın net bir şekilde birbirinden ayrılmaması nedeniyle, araştırmacılar çoğunlukla bilimin doğası ile ilgili ölçekler geliştirmiş ve çalışmalar yapmıştır. Abd-El-Khalick (2014), kişilerin bilimin doğası anlayışlarını değerlendirmek için geliştirilen ölçeklerle ilgili yaptığı literatür çalışmasında bazı ölçeklerde bilimin doğası ve bilimsel sorgulamanın doğası özelliklerinin birlikte yer aldığını ve bunlarında çoğunlukla Likert tarzı nicel ölçeklerle değerlendirilmeye çalışıldığını ortaya koymuştur (örn; NOSS; Kimball, 1968; SUSSI; Liang vd., 2006). Bu ölçekler arasından yukardaki bölümlerde bahsedilen çerçeveye uygun olarak sadece bilimsel sorgulamanın doğasına odaklanan iki ölçek bulunmaktadır (VOSI; Schwartz vd., 2008; VASI; Lederman vd., 2014). Her iki ölçekte aynı araştırmacı grup tarafından 
geliştirilmiştir ve kişilerin bilimsel sorgulamanın doğası hakkındaki görüşlerini açk uçlu sorularla ölçmeyi hedeflemiştir. Bilimsel Sorgulamanın Görüşleri (VOSI; Schwartz, 2004; Schwartz vd., 2008) anketi aslında öğrencilerin, öğretmenlerin ve bilim adamlarının bilimsel araştırmanın doğası hakkındaki anlayışlarını ölçmek için geliştirilmiş bir araçtır. Belirtildiği gibi, değerlendirilen bilimsel araştırmanın yönleri, fen eğitimcileri ve diğer araştırmacıların çalışmaları ile birlikte çeşitli reform belgelerinin kapsamlı bir incelemesiyle belirlenmiştir (Schwartz vd., 2008). VOSI'nin ilk sürümü, bilimsel sorgulamanın beş yönünü ele alan beş soruluk, açık uçlu ankettir. VOSI'nin ayrıca uygun okuma ve yazma becerileri olmayan kişiler için bir sözlü protokolü de mevcuttur. Her ne kadar VOSI ölçeği araştırmacılara geçerli ve güvenilir sonuçlar veresede, bilimsel sorgulama ile ilgili güncellenen reform dokümanlarında (NGSS leads state, 2013) ve yukardaki bölümlerde detaylı bir şekilde açıklanan, bilimsel sorgulamanın doğası özelliklerinin tüm yönlerini içermediği belirlenmiştir. Bu nedenle Lederman vd. (2014) VOSI' yi güncelleyerek daha kapsamlı bir ölçek olan VASI (Lederman vd., 2014) ölçeğini meydana getirmişlerdir. VASI ölçeği, Ulusal Bilim Eğitimi Standartları (NRC, 2000) tarafından tanımlanan ve yukardaki bölümlerde belirtilen bilimsel araştırmanın farklı yönlerine dayanan, bağlamsal hale getirilmiş yedi açık uçlu soru içermektedir. Ölçeğin uygulandıktan sonra yarı yapılandırılmış takip edici mülakatlar ile desteklenmesi ve katılımcıların görüşlerinin daha ayrıntılı anlaşılması önerilmektedir (Schwartz vd., 2008; Lederman vd., 2014). Ayrıca, VASI anketi de enstrümanın geliştiricileri tarafından yürütülen bir uluslararası proje doğrultusunda Türkiye' deki başka araştırmacılarla çevirisi-geri çevirisi-pilot uygulaması yapılarak Türkçe'ye çevrilmiştir (Lederman et al, 2019).

\section{Bilimsel Sorgulamanın Doğası İle İlgili Yapılan Araştırmalar}

Yapılan araştırmalar; bilimin doğası ve bilimsel sorgulamanın aynı kavramlar gibi algılanması (Lederman vd., 2014), bilimsel sorgulamanın doğası hakkındaki görüşleri ortaya koyacak ölçme araçlarının yetersiz olması (Lederman vd., 2019), sorgulama yapmayı sorgulama hakkında anlayış sahibi olmakla eşitleyen inançlar (Lederman vd., 2014) ve bu inanca bağlı olarak yapılan çalışmaların büyük bir kısmında bilimsel sorgulama etkinliklerinin et- 
kililiğine odaklanılması (Şenler, 2017) nedeniyle, öğrencilerin ve öğretmenlerin bilimsel sorgulamanın doğası hakkındaki görüşlerini araştıran ve bu görüşleri geliştirmeyi amaçlayan çalışmaların oldukça sınırlı olduğunu ortaya koymaktadır.

Alan yazın incelendiğinde yapılan çalışmaların çoğunlukla ortaokul/lise öğrencileri ve öğretmen adayları ile yapıldığı görülmektedir. Daha küçük yaşlardaki çocuklarla yapılan sınırlı sayıdaki çalışmaların bulguları bu çocukların bilimsel sorgulama hakkındaki görüşlerinin sınırlı olduğunu ortaya koymaktadır (Lederman, 2012; Lederman, Bartels, Liu ve Jimenez, 2013; Lederman ve Lederman, 2004). Benzer şekilde orta okul (Doğan, Han-Tosunoğlu, Özer ve Akkan, 2020; Leblebicioğlu vd, 2019; Lederman vd., 2014; Lederman vd., 2019; Şenler, 2015; Yang, Park, Shin, ve Lim, 2017) ve lise düzeyinde yapılan çalışmalar (Anggraeni, Adisendjaja, ve Amprasto, 2017; Aydeniz, Baksa ve Skinner, 2011; Bell, Blair, Crawford ve Lederman, 2003; Leblebicioğlu, vd., 2020) öğrencilerin bilimsel sorgulamanın doğası hakkındaki görüşlerinin yetersiz olduğunu ortaya koymaktadır. Yine öğretmen adayları ile yapılan çalışmalarda öğretmen adaylarının bu konudaki görüşlerinin yetersiz olduğunun vurgulandığı görülmektedir (Baykara ve Yakar, 2020; Baykara, Yakar ve Liu, 2018; Bostan-Sarıoğlan, 2018; Crawford, Zembal-Saul, Munford ve Friedrichsen, 2005; Doğan, 2017; Haefner ve Zembal-Saul, 2004; Karışan, Bilican ve Şenler, 2017; Mesci, Çavuş-Güngören ve Yeşildağ-Hasancebi, 2020; Schwarz, 2009; Şenler, 2017).

Bilimsel sorgulamanin derslerde benimsenmesi ve öğrencilerin bu konudaki görüşlerinin geliştirilmesi sürecindeki en kritik aktör bunu bir öğretim yaklaşımı olarak kullanacak öğretmenlerdir (Bostan-Sarıŏlan, 2018). Bir konuyu tam anlamıyla bilmeden onu başkalarına öğretmek veya bir öğretim yaklaşımını bilmeden derslerde kullanarak istenen verimi almak mümkün değildir (Baykara ve Yakar, 2020; Karışan, Bilican ve Şenler, 2017). Bilimsel sorgulama hakkındaki anlayış eksikliği, öğretmenlerin bilimsel sorgulama derslerini uygulamadaki engellerinden biridir (Roehring ve Luft, 2004). Bu sebeple, öğretmenlerin, bilimsel bilginin temelini oluşturan ve bilimsel araştırmalara yön veren bilimsel sorgulamanın doğasını anlamaları, bilimsel sorgulama uygulamalarını gerçekleştirebilmeleri için büyük bir önem arz etmektedir (Zion ve Mendelovici, 2012). 
Öğretmenlerin bilimsel sorgulamanın doğası hakkındaki görüşlerinin araştırıldığı ve geliştirilmeye çalışıldığı çalışmaların bulguları genel olarak incelendiğinde; öğretmenlerin görüşlerinin yetersiz olduğu (Akerson ve Hanuscin, 2007; Crawford, Capps, Meyer, Petel ve Ross, 2010; Dudu, 2014; Wang ve Zhao, 2016), öğretmenlerin bilimsel sorgulamanın doğasını öğretmeyi ana hedef olarak görmedikleri, daha çok bilimsel sorgulama yapmaya ve bu konudaki becerileri geliştirmeye odaklandıkları (Strippel ve Sommer, 2015), öğretmenlerin bilimsel sorgulamanın doğası hakkındaki görüşlerini geliştirmeye yönelik yapılan çalışmaların öğretmenler üzerinde genellikle pozitif bir etki oluşturduğu (Bahbah vd., 2013; Çiğdemoğlu ve Köseoğlu, 2019; Lederman ve Lederman, 2004; Lotter, Harwood ve Bonner, 2006); ancak öğretmenlerle yapılan çalışmaların genel anlamda oldukça sınırlı olduğu ortaya çıkmaktadır.

\section{Sonuç ve Öneriler}

Bilimsel sorgulama bilim okuryazarlığının temel bileşenlerinden biridir. Dolayısıyla bilimsel sorgulamanın sınıf içi etkinliklerde uygulanması ve bilimsel sorgulamanın doğası özelliklerinin konu içeriği olarak ele alını içerik tabanlı veya klasik etkinliklerle öğretilmesi önemlidir (Akerson ve Hanuscin, 2007; Mesci ve Erdaş-Kartal, 2020). Herhangi bir fen konusunun kazanımlarının ders içinde kendiliğinden yani dolaylı bir şekilde öğrenilmesinin beklenilmediği gibi, bu bileşenlerin de yapılacak bir fen dersinin içinde dolaylı olarak öğrenciler tarafından kendiliğinden anlaşılması beklenmemelidir. Dolayısıyla bilimsel sorgulamanın doğası özelliklerinin fen konularının gölgesinde kalmamasına dikkat edilmelidir. Yapılan araştırmalar dolaylı öğretimin hem bilimin doğasının hem de bilimsel sorgulamanın doğasının öğretiminde pek işe yaramadığını desteklemektedir (Khishfe ve Abd-El-Khalick, 2002). Bu konuda bilimin doğası ile ilgili oldukça fazla çalışma olmasına rağmen, bilimsel sorgulamanın doğasının öğretiminde dolaylı veya açık-yansıtıcı yaklaşımın etkilerinin araştırılmasına yönelik çalışmalara ihtiyaç hala devam etmektedir.

Alan yazındaki araştırmalar, bilimsel sorgulamanın doğası hakkındaki çalışmaların yetersizliğini, var olan çalışmalar ise katılımcıların genel olarak bilimsel sorgulamanın doğası hakkında gelişmemiş görüşlere sahip olduklarını göstermektedir. Bu nedenle, özellikle okul öncesinden üniversiteye kadar 
öğrencilerin, bilimsel sorgulamanın doğası öğretiminin uygulayıcıları olacak öğretmen ve öğretmen adaylarının bilimsel sorgulamanın doğası hakkındaki görüşlerinin geliştirilmesi ile ilgili çalışmalara ihtiyaç duyulmaktadır. Açı/yansıtıcı yaklaşımın farklı uygulamaların bilimin doğası ile ilgili yapılan çalışmalarda görmek mümkündür (PCK-tabanlı NOS öğretimi; Mesci, 2020). Bu bağlamda benzer uygulamaların bilimsel sorgulamanın doğası ile ilgili yapılması önerilmektedir.

Yapılan çalışmalar ve uluslararası dökümanlar bilimsel sorgulamanın bilgi ve beceri boyutunda ayrı ele alınması gerektiğini vurgularken, bilimsel sorgulama yaptırıldığında bilimsel sorgulamanın doğası hakkındaki görüşlerin kendiliğinden gelişeceğini beklemek zaman kaybı olacaktır. Bu nedenle öğretmenlerin öncelikle sınıflarında yaptırdıkları uygulamalı bilim etkinliklerinin bilimsel sorgulama olup olmadığını çalışmamızda sunulan kriterleri göz önünde tutarak değerlendirmeleri, bilimsel sorgulama olduğuna karar verdikleri etkinliklerde de bilimsel sorgulamanın doğasının bileşenlerine açık-yansitıcı bir şekilde değinmeye özen göstermeleri önerilmektedir. Bu anlamda öğretmenler sınıflarında yaptıracakları bilimsel sorgulamaları öğrencilerin düzeyine göre planlamalı, öğrencilerin sorgulama becerilerini makalede sunulan sorgulama düzeylerini dikkate alarak aşamalı bir şekilde geliştirmeyi hedeflemelidir. Öğretmenlerin "gerçek sorgulamanın sadece açık sorgulamalardan oluştuğu" algısından sıyrılması; sınıf içinde sorgulama yaptırmanın zor ve zahmetli bir süreç olduğu düşüncesiyle bu uygulamalara mesafeli yaklaşmamaları ve ilk uygulamada yaşadıkları başarısızlıktan yola çıkarak öğrencilerinden beklentilerini düşürmemeleri açısından önemlidir. Öğretmenler sınıf içindeki gündelik bilim uygulamalarına yapacakları ufak dokunuşlarla ve iyi bir planlama ile zaten halihazırda yaptıkları birçok uygulamayı öğrencilerin sorgulama becerilerini geliştirecek ve bilimsel sorgulamanın doğasını kavramalarını sağlayacak şekilde zenginleştirebilir. Araştırmacıların görevi ise; öğretmenlerin bahsedilen kavramlar hakkında sahip oldukları kafa karışıklıklarını giderecek ve pratikte işlerine yarayacak örnek planlar veya etkinlikleri içeren kaynak sunmaları, bu amaçla planlanan öğretmen eğitimi çalışmalarında ise onların pratikleri arttıracak uygulamalara yer vermeleridir.

Bu çalışma ülkemiz fen eğitimi literatürüne, öğrencilerin, öğretmenlerin, öğretmen adaylarının, fen eğitimcilerinin ve araştırmacıların ana dilinde oku- 
yup bilimsel sorgulamayı ve bilimsel sorgulamanın doğasını anlayabilecekleri bir kaynaktır. Bu yönüyle bu çalışmanın; sınıf içi uygulamalarında öğretmenlere, bilimsel sorgulamanın doğası ile ilgili ülkemizde yapılacak araştırmalara yol göstereceği düşünülmektedir. 


\title{
EXTENDED ABSTRACT
}

\section{Scientific Inquiry and Nature Of Scientific İnquiry From Theory To Practice}

\author{
Eda Erdaş Kartal- Günkut Mesci \\ Kastamonu University, Giresun University
}

The primary goal of the science curricula in many countries as well as Turkey is to raise science literate individuals who are researching, questioning, producing and adapting to change and having high level thinking skills. (Ministry of National Education (MEB), 2018, NGSS Lead States, 2013). Although the idea of teaching scientific inquiry has a long history in science education, today there is still a confusion about what is meant by teaching scientific inquiry (Bell, Smetena, \& Bills, 2005; Bybee, 2000; Lederman et al., 2014). In order to get rid of this confusion, it is thought that there is a need for theoretical studies that reveal what exactly scientific inquiry is and what it covers, and which aspects of scientific inquiry differ from nature of science. Similar to other countries, although nature of science has been studied for many years in our country as well, there are limited evidence about what scientific inquiry corresponds to in classroom science teaching, determining the understanding of students or teachers about scientific inquiry, and developing students' understanding about nature of scientific inquiry (Mesci and Erdaş-Kartal, 2021). This study is a theoretical research paper to fill this gap in the national literature.

Teachers and science educators still face various uncertainties regarding the particular characteristics of scientific inquiry and the nature of science and their integration into existing science teaching and science curriculum (Flick \& Lederman, 2006; Park, 2008).The concepts of scientific inquiry and the nature of science are often used interchangeably (Lederman et al., 2014). Although nature of science and scientific inquiry are closely related, they have different structures (Flick \& Lederman, 2006; Lederman, 2019). Nature of science refers to certain characteristics that limit and do not limit the use and ontological foundation of scientific knowledge produced as a result of scientific inquiry, as a human enterprise (Flick \& Lederman, 2006). To put it 
more clearly, nature of science is the values and assumptions inherent in the production and development of scientific knowledge produced in the process of scientific inquiry (Lederman, 1992). While scientific inquiry expresses the concrete processes about how scientists do their work and how the resulting scientific knowledge is produced and accepted; nature of science refers to the characteristics of scientific knowledge derived from how scientific knowledge is developed, and the features that distinguish science from disciplines such as religion and history (Nehring, 2019; NGSS, 2013; Lederman, 2006; Lederman et al., 2014).

Nature of scientific inquiry expresses the characteristics of the scientific inquiry process (Deniz \& Akerson, 2013; Lederman et al., 2014; Schwartz, 2004). Researchers mostly have a common view about what these features are (Lederman et al., 2014; Osborne et al., 2003; Schwartz, Lederman, \& Lederman, 2008). Accordingly, the components of scientific inquiry can be summarized in 8 categories (Lederman et al., 2014; Lederman et al., 2019): (a) all scientific research starts with a question, but it doesn't always have to test a hypothesis, (b)there is no single and step-by-step scientific method used in all scientific research, (c) research questions guide the scientific inquiry process, (d) even all scientists perform the same procedures may not achieve the same results, (e) scientific inquiry procedures have an impact on the results, (f) there should be consistency between research findings and data collected, (g) scientific data and scientific evidence are not the same, (h) scientific explanations are developed in the light of previously known and collected data.

It is important to apply scientific inquiry in classroom activities and to consider the nature of scientific inquiry as subject content and to be taught with content-based or classical activities (Akerson \& Hanuscin, 2007; Mesci \& Erdaş-Kartal, 2020). Just as the acquisitions of any science subject are not expected to be learned indirectly in the course, it should not be expected that the components of nature of scientific inquiry will be understood by students indirectly in a science lesson. Therefore, it should be taken not to overshadow nature of scientific inquiry by science subjects. Studies support that implicit approach does not work well in teaching both nature of science and nature of scientific inquiry (Khishfe and Abd-El-Khalick, 2002). Although there are many studies on teaching of nature of science, there is still a 
need for studies to investigate the effects of implicit or explicit-reflective approach in teaching of nature of scientific inquiry.

Research in the literature indicates the inadequacy of studies on nature of scientific inquiry, and existing studies show that participants generally have navie views about nature of scientific inquiry. Therefore, there is a need for studies on the development of the views of teachers and teacher candidates, who will be the practitioners of teaching nature of scientific inquiry, especially from preschool to university, on nature of scientific inquiry. It is possible to see different applications of the explicit/reflective approach in studies on nature of science (PCK-based NOS teaching; Mesci, 2020). In this context, it is suggested that similar studies should be conducted regarding teaching of nature of scientific inquiry.

This study is a resource for national science education literature, where students, teachers, teacher candidates, science educators and researchers may read in their native language and understand the nature of scientific inquiry and scientific inquiry. Also, it is thought that this study will guide to conduct future research about nature of scientific inquiry.

\section{Kaynakça / References}

Abd-El-Khalick, F. (2014). The evolving landscape related to assessment of nature of science. In Handbook of Research on Science Education içinde (s. 621-650). Taylor and Francis. https://doi.org/10.4324/9780203097267

Abell, S. K., Smith, D. C., ve Volkmann, M. J. (2006). Inquiry in science teacher education. In Scientific inquiry and nature of science içinde (s. 173-199). Dordrecht: Springer.

Anggraeni, N., Adisendjaja, Y. H., ve Amprasto, A. (2017). Profile of high school students' understanding of scientific inquiry. Journal of Physics: Conference Series, 895, 1-5.

Akerson, V. L., ve Hanuscin, D. L. (2007). Teaching nature of science through inquiry: Results of a3-year professional development program. Journal of Research in Science Teaching, 44(5), 653-680.

American Association for the Advancement of Science [AAAS]. (1989). Science for all Americans. Washington, DC.

American Association for the Advancement of Science [AAAS]. (1993). Benchmarks for science literacy. NewYork: Oxford University Press.

Anderson, R. D. (2002). Reforming science teaching: What research says about inquiry. Journal of Science Teacher Education, 13(1), 1-12. 
Aydeniz, M., Baksa, K., ve Skinner, J. (2011). Understanding the impact of an apprenticeship-based scientific research program on high school students' understanding of scientific inquiry. Journal of Science Education and Technology, 20(4), 403-421.

Bahbah, S., Golden, B. W., Roseler, K., Elderle, P., Saka, Y., ve Shoutherland, S. A. (2013). The Influence of RET's on elementary and secondary grade teachers' views of scientific inquiry. International Education Studies, 6(1), 117-131.

Banchi, H., ve Bell, R. (2008). The many levels of inquiry. Science and Children, 46(2), 26-29.

Baykara, H., Yakar, Z., ve Liu, S. Y. (2018). Preservice science teachers' views about scientific inquiry. European Journal of Education Studies, 4(10), 128-143.

Baykara, H., ve Yakar, Z. (2020). Preservice science teachers' views about scientific inquiry: The case of Turkey and Taiwan. Turkish Online Journal of Qualitative Inquiry, 11(2), 161-192.

Bell, R. L., Blair, L. M., Crawford, B. A., ve Lederman, N. G. (2003). Just do it? Impact of a science apprenticeship program on high school students' understandings of the nature of science and scientific inquiry. Journal of Research in Science Teaching, 40(5), 487-509.

Bell, R. L., Smetana, L., ve Binns, I. (2005). Simplifying inquiry instruction. The Science Teacher, 72 (7), 30-33.

Bell, T., Urhahne D., Schanze S., ve Ploetzner R. (2010). Collaborative inquiry learning: Models, tools, and challenges. International Journal of Science Education, 32(3), 349-377.

Bostan-Sarıoğlan, A. (2018). Fen bilgisi öğretmen adaylarının öğretim deneyimlerinden sonra bilimsel sorgulama hakkındaki görüşlerinin değerlendirilmesi. Mehmet Akif Ersoy Üniversitesi Ĕ̆itim Fakültesi Dergisi, 48, 136159.

Branch, J.L., ve Solowan, D.G. (2003). Inquiry-based learning: The key to student success. School Libraries in Canada, 22(4), 6-12.

Buck, L. B., Bretz, S. L., ve Towns, M. H. (2008). Characterizing the level of inquiry in the under- graduate laboratory. Journal of College Science Teaching, 38(1), 52-58.

Bunterm, T., Lee, K., Ng Lan Kong, J., Srikoon, S., Vangpoomyai, P., Rattanavongsa, J., \& Rachahoon, G. (2014). Do Different Levels of Inquiry Lead to Different Learning Outcomes? A comparison between guided and structured inquiry. International Journal of Science Education, 36(12), 1937-1959. doi:10.1080/09500693.2014.886347 
Bybee, R. W. (2000). Teaching science as inquiry. J. Minstrell \& E. van Zee (Eds.), Inquiry into inquiry learning and teaching in science içinde (s. 20-46). Washington, DC:American Association for the Advancement of Science.

Bybee, R. W. (2006). Scientific inquiry and science teaching. L. Flick \& N.G. Lederman (Eds.) Scientific inquiry and nature of science içinde (s. 1-14). Springer, Dordrecht.

Crawford, B (2014). From inquiry to scientific practices in the science classroom. In N. G. Lederman \& S. K. Abell (Eds.), Handbook of research on science education (Vol 2, pp. 515-541). New York: Routledge.

Crawford, B. A., Capps, D., Meyer, X., Patel, M., ve Ross, R. M. (2010, April). Supporting teachers in complex situations: Learning to teach evolution, nature of science, and scientific inquiry. A paper presentation at the American Educational Research Association Annual Meeting-Denver, Colorado.

Crawford, B. A., Zembal-Saul, C., Munford, D., ve Friedrichsen, P. (2005). Confronting prospective teachers' ideas of evolution and scientific inquiry using technology and inquiry-based tasks. Journal of research in science teaching, 42(6), 613-637.

Çiğdemoğlu, C., ve Köseoğlu, F. (2019). Improving science teachers' views about scientific inquiry. Science $\mathcal{E}$ Education, 28, 439-469.

Deniz, H., ve Akerson, V. (2013). Examining the impact of a professional development program on elementary teachers' views of nature of science and nature of scientific inquiry, and science teaching efficacy beliefs. The Electronic Journal for Research in Science \& Mathematics Education, 17(3), 1-19.

Dogan, N. (2017). Blending problem based learning and history of science approaches to enhance views about scientific inquiry: New wine in an old bottle. Journal of Education and Training Studies, 5(10), 99-112.

Doğan, N., Han-Tosunoglu, Ç., Özer, F., ve Akkan, B. (2020). Ortaokul öğrencilerinin bilimsel sorgulama görüşleri: Cinsiyet, sınıf düzeyi ve okul türü değişkenlerinin incelenmesi. Pamukkale Üniversitesi Ĕ̆itim Fakültesi Dergisi, 49, 162189.

Dudu, W. T. (2014). Exploring South African high school teachers' conceptions of the nature of scientific inquiry: a case study. South African Journal of Education, 34(1), 1-18.

Duschl, R. A., Schweingruber, H. A., ve Shouse, A. W. (2007). Taking science to school: Learning and teaching science in grades K-8. Washington, DC: National Academies Press. 
Flick, L. B., ve Lederman, N. G. (2006). Scientific inquiry and nature of science; Implication for teaching, learning and teacher education. Dordrecht: Springer.

Haefner, L. A. ve Zembal-Saul, C. (2004). Learning by doing? Prospective elementary teachers' developing understandings of scientific inquiry and science and learning. International Journal of Science Education, 26 (13), 1653-1674.

Herron, M.D. (1971). The nature of scientific inquiry. School Review 79(2), 171-21

Hodson, D. (2014). Learning science, learning about science, doing science: Different goals demand different learning methods. International Journal of Science Education, 35 (15), 2534-2553.

Karışan, D., Bilican, K., veŞenler, B. (2017). Bilimsel sorgulama hakkında görüş anketi: Türkçeye uyarlama, geçerlik ve güvenirlik çalışması. Inönü Üniversitesi Eğitim Fakültesi Dergisi, 18(1), 326-343.

Khishfe, R., ve Abd-El-Khalick, F. (2002). The influence of explicit reflective versus implicit inquiry-oriented instruction on sixth graders' views of nature of science. Journal of Research in Science Teaching, 39(7), 551 - 578.

Kimball, M. E. (1968). Understanding the nature of science: A comparison of scientists and science teachers. Journal of Research in Science Teaching, 5, 110- 120.

Koyunlu-Ünlü, Z. (2020). Improving pre-service teachers' science process skills and views about scientific inquiry. Kuramsal Eğitimbilim Dergisi [Journal of Theoretical Educational Science], 13(3), 474-489.

Leblebicioglu, G., Abik, N. M., Capkinoglu, E., Metin, D., Eroglu Dogan, E., Cetin, P. S., ve Schwartz, R. (2019). Science camps for introducing nature of scientific inquiry through student inquiries in nature: Two applications with retention study. Research in Science Education, 49(5), 1231-1255.

Leblebicioğlu, G., Çapkınoğlu, E., Peten, D. M., ve Schwartz, R. S. (2020). Views of nature of scientific inquiry of students in different high schools. Education $\mathcal{E}$ Science/Egitim ve Bilim, 45(201), 143-165.

Lederman, J. S. (2012). Development of a valid and reliable protocol for the assessment of early childhood students' conceptions of nature of science and scientific inquiry. A Paper Presented at the Annual Meeting of the National Association of Research in Science Teaching, Indianapolis, IN.

Lederman, J. S., Bartels, S. L., Liu, C., ve Jimenez, J. (2013). Teaching nature of science and scientific inquiry to diverse classes of early primary level students. A Paper Presented at the Annual Meeting of the National Association for Research in Science Teaching (NARST), San Juan, PR, USA.

Lederman, J. S., ve Lederman, N. G. (2004). Early Elementary Students' and Teacher's Understandings of Nature of Science and Scientific Inquiry: Lessons Learned from 
Project ICAN. Paper Presented at the Annual Meeting of the National Association for Research in Science Teaching, Vancouver, British Columbia, April, 2004.

Lederman, J. S., Lederman, N. G., Bartos, S. A., Bartels, S. L., Meyer, A. A., \& Schwartz, R. S. (2014). Meaningful assessment of learners' understandings about scientific inquiry - The views about scientific inquiry (VASI) questionnaire. Journal of Research in Science Teaching, 51(1), 65-83.

Lederman, J.S., Lederman, N.G., Bartels, S., Jimenez, J., Akubo, M., vd. (2019). An international collaborative investigation of beginning seventh grade students' understandings of scientific inquiry: Establishing a baseline. Journal of Research in Science Teaching, 56(4), 486-515.

Lederman N. G. (1992). Students' and teachers' conceptions of the nature of science: a review of the research, Journal of Research in Science Teaching, 29, 331-59.

Lederman, N.G. (2006). Research on nature of science: reflections on the past, anticipations of the future. Asia-Pasific Forum Science Learning and Teaching, 7 (1), 111

Lederman, N. G. (2019). Contextualizing the relationship between nature of scientific knowledge and scientific inquiry. Science E Education, 28, 249-267.

Lederman, N. G., Antink, A., ve Bartos, S. (2014). Nature of science, scientific inquiry, and socio-scientific issues arising from genetics: A pathway to developing a scientifically literate citizenry. Science E Education, 23(2), 285-302.

Lederman, N. G. ve Lederman, J.S. (2004). Project ICAN: A professional development project to promote teachers' and students' knowledge of nature of science and scientific enquiry. In Proceedings of the 11th Annual SAARMSTE Conference. Cape Town, South Africa.

Lederman, N., ve Lederman, J. (2012). Nature of scientific knowledge and scientific inquiry: Building instructional capacity through professional development. In B. J. Fraser, K. Tobin \& C. J. McRobbie(Eds.), Second International Handbook of Science Education (24th ed.), (pp. 335-359). Dordrecht: Springer

Lederman, N. G., Lederman, J. S., ve Antink, A. (2013). Nature of science and scientific inquiry as contexts for the learning of science and achievement of scientific literacy. International Journal of Education in Mathematics, Science and Technology, 1(3), 138-147. 
Liang, L. L., Chen, S., Chen, X., Kaya, O. N., Adams, A. D., Macklin, M., ve Ebenezer, J., (2006). Student understanding of science and scientific inquiry: revision and further validation of an assessment instrument. In Paper presented at the Annual Conference of the National Association for Research in Science Teaching (NARST). San Francisco, CA.

Lotter, C., Harwood, W. S., ve Bonner, J. J. (2006). Overcoming a learning bottleneck: Inquiry professional development for secondary science teachers. Journal of Science Teacher Education, 17(3), 185-216.

Martin-Hansen, L. (2002). Defining inquiry: Exploring the many types of inquiry in the science classroom. Science Teacher, 69(2), 34-37.

Mesci, G. (2020). The influence of PCK based NOS teaching on pre-service science teachers' NOS views. Science \& Education. Doi: 10.1007/s11191-020-00117-7

Mesci, G. ve Erdas-Kartal, E. (2021). Science teachers' views on nature of scientific inquiry. Bartm University Journal of Faculty of Education, 10(1), 69-84. https://doi.org/10.1016/buefad.797246

Mesci, G., Çavuş-Güngören, S., ve Yesildag-Hasancebi, F. (2020). Investigating the development of pre-service science teachers' NOSI views and related teaching practices. International Journal of Science Education, 42(1), 50-69.

Metz, K. E. (2004). Children's understanding of scientific inquiry: Their conceptualization of uncertainty in investigations of their own design. Cognitionand Instruction, 22(2), 219-290.

Milli Eğ̈tim Bakanlığı (2018). Fen bilimleri dersi (3, 4, 5, 6, 7 ve 8. stmıflar) öğretim programı. Ankara: Milli Ĕ̈itim Basımevi.

Minner, D. D., Levy, A. J., ve Century, J. (2010). Inquiry-based science instructionwhat is it and does it matter? Results from a research synthesis years 1984 to 2002. Journal of Research in Science Teaching, 47(4), 474-496.

National Research Council [NRC] (2000). Inquiry and the national science education standards. Washington, DC: National Academy Press.

National Research Council [NRC] (1996). National science education standards. Washington, DC: National Academic Press.

National Research Council [NRC] (2011). A framework for K-12 science education: Practices, crosscutting concepts, and core ideas. Washington, DC: National Academy Press.

National Research Council [NRC] (2012). A framework for K-12 science education: Practices, crosscutting concepts, isseppand core ideas. Washington DC: National Academy Press. 
Nehring, A. (2019). Naive and informed views on the nature of scientific inquiry in large-scale assessments: Two sides of the same coin or different currencies? Journal of Research in Science Teaching. 57, 510-535. https://doi.org/10.1002/tea.21598

NGSS Lead States. (2013). Next generation science standards: For states, by states. Washington, DC: The National Academy Press.

NGSS Lead States (2014). Next Generation Science Standards: For states, by states. Washington, DC: National Academies Press.

Oğuz Ünver, A., ve Yürümezoğlu, K. (2014). Primary science students ${ }^{\text {ee }}$ approaches to inquiry-based learning. International Online Journal of Primary Education, 3 (2), 76-84.

Osborne, J. (2014). Scientific practices and inquiry in the science classroom. In N. Lederman \& S. Abell (Eds.), The handbook of research on science education, vol. II (pp. 579-599). New York: Taylor and Frances Group.

Osborne, J. F., Ratcliffe, M., Collins, S., Millar, R.. ve Duschl, R. (2003). What 'ideasabout- science' should be taught in school science? A Delphi Study of the 'Expert' Community. Journal of Research in Science Teaching, 40(7), 692-720.

Park, J. (2008). Discussions for linking the nature of science (NOS) with scientific inquiry. Journal of the Korean Association for Science Education, 28(7), 749-758.

Pedaste, M., Mäeots, M., Siiman, L. A., de Jong, T., van Riesen, S. A. N., Kamp, E. T., et al. (2015). Phases of inquiry-based learning: Definitions and the inquiry cycle. Educational Research Review, 14, 47-61.

Rezba, R.J., T. Auldridge, and L. Rhea. (1999). Teaching E learning the basic science skills. Available online at www.pen.k12.va.us/VDOE/instruction/TLBSSGuide.doc

Roehrig, G. H., ve Luft, J. A. (2004). Constraints experienced by beginning secondary science teachers in implementing scientific inquiry lessons. International Journal of Science Education, 26(1), 3-24

Sadeh, I., ve Zion, M. (2009). The development of dynamic inquiry performances within an open inquiry setting: A comparison to guided inquiry setting. Journal of Research in Science Teaching, 46(10), 1137-1160.

Schwab, J.J. (1962). The teaching of science as inquiry. In J. J. Schwab and P. F. Brandwein (Eds.), The teaching of science (pp.3-103). Cambridge, MA: Harvard University Press.

Schwartz, R.S. (2004). Epistemological views in authentic science practices: a cross- discipline comparison of scientists' views of nature of science and scientific inquiry. Unpublished doctoral dissertation, Oregon State University, Corvallis, Oregon. 
Schwartz, R. S., Lederman, N., ve Crawford, B. A. (2004). Developing views of nature of science in an authentic context: An explicit approach to bridging the gap between nature of science and science inquiry. Science Education, 88, 610-645.

Schwartz, R. S., Lederman, N. G., ve Lederman, J. S. (2008, March). An instrument to assess views of scientific inquiry: The VOSI questionnaire. Paper presented at National Association for Research in Science Teaching Conference, Baltimore, US.

Schwartz, R. S., Lederman, N., Khishfe, R., Lederman, J. S., Matthews, L., ve Liu, S., (2002) Explicit/ reflective instructional attention to nature of science and scientific inquiry: Impact on student learning. Paper presented at the 2002 Annual International Conference of the Association for the Education of Teachers in Science. Charlotte, NC.

Schwarz, C. (2009). Developing preservice elementary teachers' knowledge and practices through modeling-centered scientific inquiry. Science Education, 93(4), $720-744$.

Şenler, B. (2015). Middle school students' views of scientific inquiry: An international comparative study. Science Education International, 26(2), 166-179.

Şenler, B. (2017). Examination of pre-service science teachers' science teaching selfefficacy beliefs and views about scientific inquiry. Egitim Kuram ve Uygulama Araștırmaları Dergisi, 3(2), 50-59.

Strippel, C., ve Sommer, K. (2015). Teaching nature of scientific inquiry in chemistry: how do German chemistry teachers use labwork to teach NOSI? International Journal of Science Education, 37(18), 2965-2989.

Tytler, R., ve Peterson, S. (2003). Tracing young children's scientific reasoning. Research in Science Education, 33(4), 433-465.

Wang, J., ve Zhao, Y. (2016). Comparative research on the understandings of nature of science and scientific inquiry between science teachers from Shanghai and Chicago. Journal of Baltic Science Education, 15(1), 97.

Wilson, C. D., Taylor, J. A., Kowalski, S. M., ve Carlson, J. (2010). The relative effects and equity of inquiry- based and common place science teaching on students' knowledge, reasoning, and argumentation. Journal of Research in Science Teaching, 47 (3), 276-301.

Wong, S., ve Hodson, D. (2010). More from the horse's mouth: What scientists say about science as a social practice. International Journal of Science Education, 32(11), 1431-1463. 
Yang, I. H., Park, S. W., Shin, J. Y., ve Lim, S. M. (2017). Exploring Korean middle school students' view about scientific inquiry. Eurasia Journal of Mathematics Science and Technology Education, 13(7), 3935-3958.

Zion, M., ve Mendelovici, R. (2012). Moving from structured to open inquiry: Challenges and limits. Science Education International, 23(4), 383-399.

\section{Kaynakça Bilgisi / Citation Information}

Erdaş-Kartal, E. ve Mesci, G. (2021). Teoriden uygulamaya bilimsel sorgulama ve bilimsel sorgulamanın doğası. OPUS-Uluslararası Toplum Araştırmaları Dergisi, 17(37), 4646-4676. DOI: 10.26466/opus.861829 